\title{
Citraan pada Kumpulan Puisi Bertema Musim Gugur Karya Goethe
}

\author{
Prahoro Yudo Purwono ${ }^{1}$ \\ ${ }^{1}$ Program Studi Sastra Jerman, Fakultas Bahasa dan Seni,Universitas Negeri Surabaya, \\ Jl. Kampus UNESA Lidah Wetan, Surabaya, 60213 \\ Penulis untuk Korespondensi/E-mail:prahoro.17020504011@mhs.unesa.ac.id
}

\begin{abstract}
Imagery plays an important role in literary works, and poetry is no exception. In Goethe's poetry, the romantic era which tries to describe the beauty of nature as the main object is very strong. One of the natural beauties that are trying to be described and famous is autumn in Germany. This natural phenomenon is trying to be described through imagery, so readers need to understand the imagery in poetry to get a clear picture and understand the intent or message in the poem. This study aims to describe the meaning related to imagery and the types of imagery contained in Goethe's poems. The research method used is qualitative with the theory of Pradopo. The results showed that in the process of understanding the images or images contained in poetry, an understanding of the meaning contained in the poem as a whole was needed to get a clear picture. Meanwhile, based on the results of the analysis, found 4 types of imagery in Goethe's autumn-themed poetry, namely visual imagery, auditory imagery, tactile imagery, and motion imagery. The number of each image is 8 visual images, 2 auditory images, 2 tactile images, and 3 motion images.
\end{abstract}

Abstrak - Citraan memainkan peran penting dalam karya sastra, tidak terkecuali puisi. Pada puisi karya Goethe, era romantik yang berusaha menggambarkan keindahan alam sebagai objek utama sangat kuat. Salah satu keindahan alam yang berusaha digambarkan dan terkenal adalah musim gugur di negara Jerman. Fenomena alam ini berusaha digambarkan melalui citraan, sehingga sangat penting bagi pembaca memahami citraan pada puisi agar mendapatkan gambaran yang jelas dan memahami maksud atau pesan dalam puisi. Penelitian ini bertujuan untuk mendeskripsikan makna terkait citraan dan jenis-jenis citraan yang terdapat dalam puisi-puisi karya Goethe. Metode penelitian yang digunakan adalah kualitatif dengan teori dari Pradopo. Hasil penelitian menunjukkan dalam proses memahami imaji atau citraan yang terdapat dalam puisi diperlukan pemahaman mengenai makna yang terdapat puisi secara keseluruhan agar mendapatkan gambaran yang jelas. Sedangkan berdasarkan hasil analisis, ditemukan 4 jenis citraan dalam puisi bertema musim gugur karya Goethe, yaitu citraan penglihatan, citraan pendengaran, citraan perabaan, dan citraan gerak. Jumlah dari masing-masing citraan tersebut yaitu 8 citraan penglihatan, 2 citraan pendengaran, 2 citraan perabaan, dan 3 citraan gerak.

Keywords-Goethe, Imagery, Poetry, Herbsgedichte

\section{PENDAHULUAN}

$\mathrm{P}$ enelitian terdahulu terkait dengan puisi bukanlah hal baru, apalagi terkait dengan citraan pada puisi. Misalnya penelitian dari Febiyanti (2014) yang berjudul "Citraan Pada Puisi Das Göttliche Karya Johann Wolfgang Von Goethe". Hasil penelitian Febiyanti (2014) menunjukkan bahwa pada puisi Das Göttliche terdapat 6 citraan penglihatan, 1 citraan pendengaran, 1 citraan perabaan, 1 citraan pencecap, dan terdapat 9 citraan gerak. Namun, penelitian Febiyanti (2014) lebih fokus kepada pengelompokan jenis-jenis citraan yang terdapat dalam puisi, sehingga kurang mengeksplor bagaimana makna citraan tersebut, padahal dalam 
analisis citraan pada puisi seyogyanya juga menjelaskan makna citraan yang dimaksud sesuai dengan konteks puisi yang ada agar lebih jelas [1]. Lebih lanjut, puisi berjudul Das Göttliche karya Goethe termasuk ke dalam jenis Epoche Klassik pada tahun 1770 yang masuk ke dalam periode romantik. Ciri khas utama dari karya sastra dalam periode ini adalah mengutamakan keindahan dan keserasian, meski pun dalam alur ceritanya juga terdapat unsur konflik batin yang kental.

Berbeda dengan penelitian Febiyanti (2014), penelitian dari Sitaniapessy et al pada 2021 terkait dengan puisi-puisi bertema Ketuhanan karya Goethe dengan judul penelitian "Refleksi Masyarakat Terhadap Ketuhanan Dalam Antologi Puisi Johan Wolfgang von Goethe" mengungkapkan bahwa puisi-puisi karya Goethe ini masih tergolong pada periode romantik sehingga makna ketuhanan yang ditemukan juga disampaikan dalam bait-bait yang kental menunjukkan keserasian mau pun keindahan alam. Sitaniapessy dalam penelitiannya juga mengungkapkan bahwa dalam keserasian dan keindahan dalam puisi periode romantik ini dapat dikembangkan ke studi lanjut terkait dengan citraan, karena penggambaran keserasian dan keindahan dapat ditemukan melalui imaji manusia [2].

Berdasarkan 2 penelitian di atas, terdapat beberapa kesenjangan yang dapat ditemukan. Dalam melakukan penelitian, kedua peneliti di atas berfokus kepada puisi dengan tema ketuhanan semata, padahal puisi-puisi karya Goethe pada periode romantik sangat banyak, sehingga perlu untuk dilakukan penelitian pada puisi lain di periode yang sama. Selain itu, semua puisi ketuhanan yang diteliti peneliti di atas juga tergolong di periode romantik yang kental akan keindahan dan keserasian sebagai poin utama. Keindahan dan keserasian ini juga menjadi dasar bahwa analisis citraan atau imaji juga berperan penting untuk mengungkap bentuk keindahan apa yang dimaksud dalam setiap puisi-puisi karya Goethe.

Lebih lanjut, berkaitan dengan pemaparan di atas, dapat dikatakan bahwa pada dasarnya, puisi memang diciptakan untuk memberikan gambaran yang jelas, menciptakan suasana khusus, membuat gambaran lebih hidup di benak dan indra pembaca, serta untuk menarik perhatian. Refleksi-refleksi masyarakat yang ditemukan mau pun pemikiranpemikiran digambarkan melalui puisi. Melalui puisi pula, seorang penyair dapat menceritakan suasana yang segar dan hidup serta sangat indah bagi para pembaca [3] .

Di sisi lain, puisi juga sebagai karya seni yang berusaha memberikan kenikmatan dan memperkaya kehidupan batin, serta dapat membangkitkan semangat hidup bagi para pembacanya. Melalui kata-kata dalam puisi, pembaca dapat memiliki gambaran yang jelas mengenai pesan yang ingin disampaikan [4]. Gambaran-gambaran ini terkadang menggunakan pengimajian, atau biasa disebut citraan. Citraan dalam puisi ini memiliki bentuk yang beragam dan biasanya digunakan untuk menggambarkan suasana yang dimaksud [5]. Di sisi lain, menurut Metzig (2020), citraan merupakan imaji yang melibatkan indera-indera manusia untuk mendapatkan gambaran konkret atas fenomena atau objek yang terdapat dalam puisi [6]. Sehingga dalam hal ini, citraan memainkan peranan penting bagi puisi. Citraan menjadikan puisi jauh lebih hidup dan pesan atau maksud yang ada dapat disampaikan kepada pembaca [7].

Lebih lanjut, jika dikaitkan dengan penelitian terdahulu yang telah dibahas di awal pendahuluan ini tentang puisi-puisi karya Goethe, dalam perkembangan puisi sebagai karya sastra Jerman, peran dari Goethe tidak bisa diabaikan. Banyak sekali puisi-puisi Goethe yang mendunia dan dikenal banyak masyarakat. Goethe merupakan salah satu tokoh penting dalam dunia sastra Jerman serta sosok berpengaruh dalam perkembangan Neoklasisme dan Romantisisme di seluruh wilayah Eropa di akhir abad ke-18 dan awal abad ke-19. Pengaruh Goethe tersebar di sepanjang Eropa, dan selama seabad ke depan karyanya merupakan sumber inspirasi utama dalam pembuatan karya sastra Jerman berupa musik, drama, hingga puisi [8].

Sebagai sastrawan Jerman yang aktif berkarya di periode 1749 hingga 1832, puisi-puisi karya Goethe memiliki ciri khas kuat yang mencerminkan karya sastra dari periode romantik, yaitu humanitas dan konflik batin. Humanitas berarti terjadinya pengekangan pada diri sendiri yang bertujuan untuk menonjolkan peri kemanusiaan manusia, sedangkan konflik batin lebih cenderung pada suatu peristiwa pertentangan yang tidak tampak karena hanya terjadi dalam pemikiran dan hati manusia [1].

Lebih lanjut, ciri khas lain yang penting dan menjadi pokok utama dalam periode romantik adalah keindahan dan keserasian [9]. Sebagai karya 
sastra periode romantik yang berkembang sejak tahun 1795-1853, puisi-puisi karya Goethe berusaha mengedepankan penggambaran keindahan yang dimaksud. Meski di beberapa puisinya juga menyinggung perihal cinta, tetapi unsur keindahan dan keserasian dalam puisi sangat kuat ditampilkan. Hal ini tercermin dari diksi yang digunakan. Untuk menggambarkan unsur keindahan dan keserasian yang berusaha dibangun dan ditonjolkan dalam puisinya, diksi yang dipakai Goethe adalah citraancitraan yang melibatkan indra-indra manusia seperti penglihatan, pendengaran, rasa, hingga imaji-imaji lain yang memang berfungsi untuk memperjelas angan-angan pembaca saat membaca puisi tersebut. Salah satu karya Goethe yang kental akan imaji adalah kumpulan puisi bertema Musim Gugur atau Herbstgedichte von Goethe. Di kumpulan puisi karya Goethe ini terdapat 8 puisi dengan judul Herbstgefühl, Novemberlied, Willst du immer weiter schweifen, Abschied, Nachgefühl, Glückliche Fahrt, Auf dem See, dan Prooemion. Dengan mengusung tema musim gugur, keserasian dan keindahan di dalam puisi-puisi tersebut sangat kental digambarkan di dalam puisi sehingga menarik untuk dikaji lebih lanjut.

Kemudian, jika merujuk pada citraan dalam puisi, permasalahan yang timbul dalam penggunaan citraan pada puisi hakikatnya adalah pemilihan kata atau diksi. Penggunaan diksi yang tepat dan sesuai akan sangat mempengaruhi daya khayal pembaca. Namun, jika diksi yang digunakan tidak tepat, maka angan-angan pembaca terkait dengan gambaran yang dimaksud penyair bisa jadi tidak tersampaikan dengan baik. Hal ini bisa berdampak pada pemaknaan yang salah terhadap citraan puisi yang dimaksud [10]. Dengan demikian, sangat penting dilakukan penelitian untuk mendeskripsikan jenis-jenis dan makna citraan dalam puisi, sehingga pembaca dapat memiliki gambaran yang utuh dan komprehensif terhadap apa yang digambarkan dalam puisi, khususnya dalam kumpulan puisi bertema musim gugur karya Goethe.

Berdasarkan pemaparan di atas, maka peneliti tertarik untuk melakukan kajian citraan pada kumpulan puisi bertema Herbst karya Goethe yang diterbitkan dalam website [1]. Penelitian ini bertujuan untuk mendeskripsikan jenis-jenis dan makna citraan yang terdapat dalam puisi-puisi karya Goethe sesuai dengan teori citraan menurut Pradopo (2017) [11]. Kebaharuan dari penelitian ini adalah objek atau korpus data dalam penelitian, yaitu 8 puisi bertema musim gugur karya Goethe. Selain itu, kebaharuan penelitian juga terdapat pada fokus kajian, di mana peneliti tidak hanya mengelompokkan data yang ditemukan ke dalam jenis-jenis citraan berdasarkan teori semata, tetapi juga menjelaskan makna dari data citraan yang ditemukan.

\section{METODE}

Metode penelitian yang digunakan adalah metode penelitian kualitatif. Objek data berasal dari 8 puisi bertema Herbst (Musim Gugur) karya Goethe pada situs https://www.gedichte-herbst-sprueche.com/ goethe.html dengan judul Herbstgefühl, Novemberlied, Willst du immer weiter schweifen, Abschied, Nachgefühl, Glückliche Fahrt, Auf dem See, dan Prooemion.

Teknik pengumpulan data yang digunakan adalah teknik dokumentasi dan studi pustaka. Teknik dokumentasi merupakan teknik pengumpulan data yang melibatkan dokumen publik sebagai materi yang dianalisis [12], di mana dalam hal ini dokumen publik yang dimaksud adalah puisi-puisi karya Goethe yang terdapat pada situs daring https://www.gedichte-herbst-sprueche.com/goethe.

html. Sedangkan studi pustaka digunakan untuk mengumpulkan teori-teori yang dibutuhkan sebagai penunjang dalam analisis citraan pada puisi.

Selanjutnya, data yang telah didapatkan kemudian dianalisis. Ada pun teknik analisis data yang digunakan sebagai berikut: 1) mengelompokkan lirik dalam puisi sesuai jenis citraan dalam bentuk tabel, 2) memparafrasekan makna citraan dalam puisi, 3) menarik kesimpulan dari data yang telah dianalisis.

\section{HASIL DAN PEMBAHASAN}

Pembahasan diawali dengan pengelompokan lirik puisi ke dalam tabel sesuai jenis citraannya. Berikut tabel disajikan untuk mempermudah analisis.

Tabel 1. Citraan dalam Puisi

\begin{tabular}{clll}
\hline No & \multicolumn{1}{c}{$\begin{array}{c}\text { Jenis } \\
\text { Citraan }\end{array}$} & Kutipan & Terjemahan \\
\hline 1 & $\begin{array}{l}\text { Citraan } \\
\text { Penglihatan }\end{array}$ & $\begin{array}{l}\text { Fetter } \\
\text { grüne, du } \\
\text { Laub, } \\
\text { Hier mein }\end{array}$ & $\begin{array}{l}\text { Hijau gemuk, } \\
\text { si dedaunan }\end{array}$ \\
& & Di sini \\
\hline
\end{tabular}




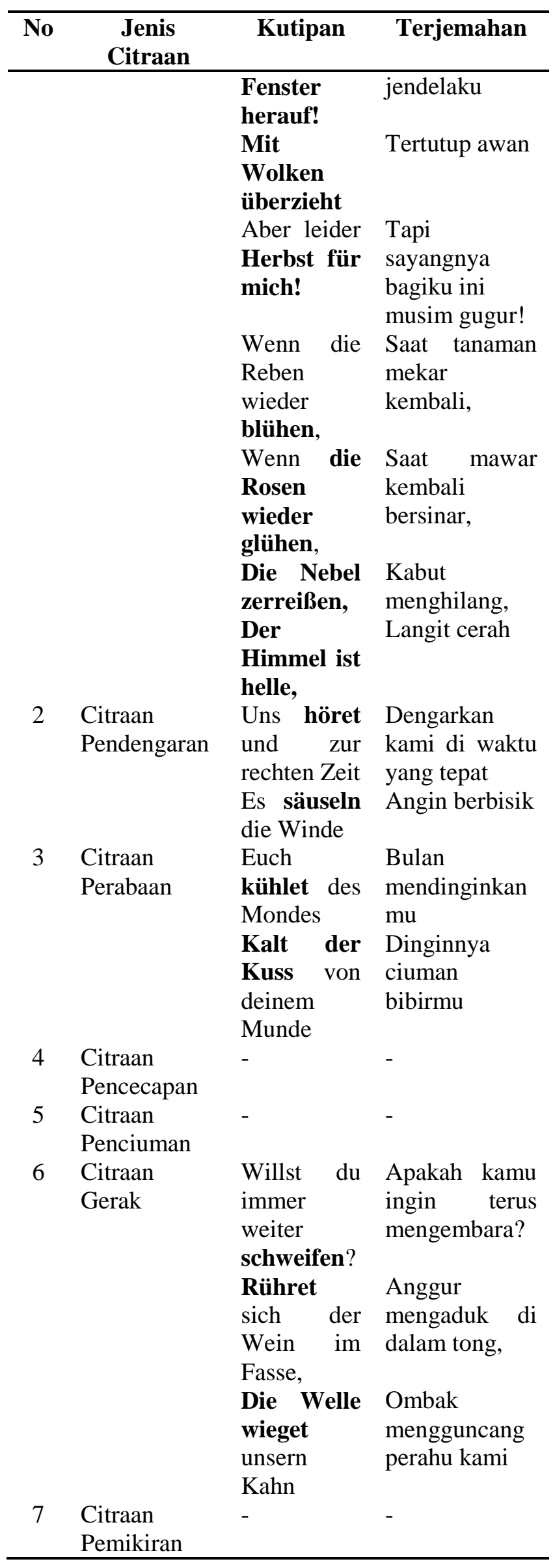

Dari Tabel 1, dapat diketahui bahwa terdapat 8 citraan penglihatan, 2 citraan pendengaran, 2 citraan perabaan, dan 3 citraan gerak. Sementara citraan pencecapan, citraan pemikiran, dan citraan penciuman tidak ditemukan di dalam puisi bertema musim gugur karya Goethe.

\section{Citraan Penglihatan}

Berdasarkan Tabel 1 , terdapat 8 citraan penglihatan yang ditemukan dalam puisi. 8 citraan ini tergolong ke dalam citraan penglihatan karena melibatkan indera penglihatan manusia untuk menjelaskan maksudnya. Seperti pada data pencitraan 1.1.

\subsection{Fetter grüne, du Laub}

Terjemahan : Hijau gemuk, si dedaunan

Pada data 1.1, frasa Fetter grüne, du Laubyang berarti hijau gemuk, si dedaunan merupakan bentuk dari citraan penglihatan. Hal ini dapat dilihat dari penggunaan warna hijau dan objek berupa daun yang hanya bisa dipahami dan dilihat oleh indra penglihatan manusia. Tanpa adanya indera penglihatan, bentuk daun yang berwarna hijau seperti yang dimaksud dalam data 1.1 tersebut tidak bisa dijelaskan secara konkret. Hal ini sesuai dengan pernyataan Pradopo (2017) yang menyatakan bahwa citraan penglihatan berfungsi untuk menjelaskan sebuah kondisi, bentuk, objek, atau entitas secara nyata yang membutuhkan indera penglihatan pembaca, sehingga pembaca seolaholah melihat secara langsung kejadian yang dimaksud [11].

Kemudian pada citraan 1.2 analisis dijabarkan sebagai berikut.

\subsection{Hier mein Fenster herauf! \\ Terjemahan : Di sini jendelaku!}

Pada data 1.2, frasa mein Fenster yang berarti jendelaku merupakan bagian dari citraan penglihatan. Kata tersebut menggambarkan objek jendelaku sebagai bagian konkret yang bisa dilihat dengan indera penglihatan manusia. Sedangkan kalimat hier mein Fenster herauf! memiliki makna orang-orang bisa menemukan jendela kamar di tempat yang dimaksud. Dengan demikian, kalimat ini melibatkan indera penglihatan pembaca agar pembaca mendapatkan gambaran konkret mengenai jendela yang dimaksud. Bila ditinjau dari jenis citraan lainnya, gambaran bentuk jendela tidak akan didapatkan oleh pembaca secara konkret apabila melibatkan indera lainnya seperti indera pencecap, penciuman, perabaan, maupun gerakan. Pradopo (2017) juga menjelaskan hal serupa, 
bahwasanya citraan penglihatan merupakan citraan yang merangsang indera penglihatan pembaca, sehingga pembaca seolah-olah melihat sendiri suasana, objek, maupun hal yang dimaksud dalam penggalan puisi [11].

Selanjutnya, citraan 1.3 dijabarkan sebagai berikut.

\subsection{Mit Wolken überzieht}

Terjemahan : Tertutup awan

Frasa Mit Wolken überzieht yang berarti tertutup awan memiliki makna bahwa penyair mengajak pembaca untuk melihat fenomena alam tentang langit yang ditutupi awan. Berdasarkan pembacaan secara heuristik, maksud dari frasa ini adalah situasi langit pada musim gugur yang tertutupi awan, tidak secerah pada musim panas. Dengan menggunakan frasa untuk mendapatkan gambaran konkret seperti ini, maka penggalan puisi ini merupakan citraan penglihatan. Dengan citraan peglihatan pada data 1.3 , pembaca dibawa oleh penyair untuk melihat secara langsung situasi yang dimaksud melalui angan-angan yang dibangun. Pradopo (2017) juga menjelaskan hal serupa, bahwasanya citraan penglihatan merupakan citraan yang merangsang indera penglihatan pembaca seakan-akan mereka melihatnya secara langsung [11]. Konsistensi penggunaan benda-benda berwujud konkret yang ditemukan di dalam puisi-puisi yang ditulis oleh Goethe ini menunjukkan bahwa citraan penglihatan memang secara langsung berkaitan dengan benda konkret, bukan hanya sekadar konsep abstrak yang juga melibatkan indera penglihatan.

Pada data 1.4 juga ditemukan hal serupa.

\subsection{Aber leider Herbst für mich!}

Terjemahan : Tapi sayangnya bagiku ini musim gugur!

Kata Herbst yang berarti musim gugur merupakan citraan penglihatan karena melibatkan indera penglihatan manusia. Pembaca seolah-olah diajak untuk melihat dan merasakan bagaimana musim gugur yang dilihat oleh penyair. Fenomena musim gugur yang dimaksud di sini berupa gugurnya daun-daun dan bunga-bunga seluruh tanaman, di mana hal ini hanya bisa diproses oleh indera penglihatan manusia, bukan oleh indera lainnya. Di sini penyair berusaha membangun angan-angan pembaca agar mendapatkan gambaran yang jelas di dalam benaknya, bahwa musim yang dinantikan sebenarnya masih belum datang dan baginya ini masih musim gugur. Hal ini sesuai dengan pendapat Pradopo (2017) yang menyatakan bahwasanya citraan penglihatan merupakan bagian dari pembentukan imaji dalam diri pembaca agar seolah-olah melihat langsung situasi yang dimaksud [11].

Tidak jauh berbeda dengan data 1.4 , pada data 1.5 juga dilakukan pendeskripsian makna dan jenis citraan sebagai berikut.

\subsection{Wenn die Reben wieder blühen,}

Terjemahan : Saat tanaman mekar kembali,

Frasa die Reben wieder blühen yang berarti tanaman kembali mekar memiliki makna bahwa terdapat tanaman-tanaman yang dimaksud oleh penyair kembali mekar. Berdasarkan hasil pembacaan secara heuristik, frasa ini merujuk pada bagaimana seseorang melihat proses mekarnya tanaman secara langsung. Dengan demikian, penyair mengajak pembaca untuk menyaksikan fenomena yang dimaksud dengan membangun imaji yang merangsang indera penglihatan pembaca. Dalam hal ini, pembaca diajak untuk membayangkan bagaimana indahnya tanamantanaman yang mekar kembali tersebut. Dengan demikian, hal ini sesuai dengan pendapat Pradopo (2017) bahwa citraan penglihatan merupakan bentuk imaji yang mendorong pembaca untuk bisa mendapatkan gambaran konkret melalui indera penglihatan atas fenomena yang dimaksud dalam puisi [11].

Selanjutnya, analisis pada data 1.6 ialah sebagai berikut.

\subsection{Wenn die Rosen wieder glühen,}

Terjemahan : Saat mawar kembali bersinar,

Menurut Metzig (2020) Bildhafte atau citraan merupakan bentuk imaji yang melibatkan otak untuk memproses gambaran yang dimaksud dalam angan-angan. Citraan ini melibatkan indera manusia, bisa penglihatan, pendengaran, maupun yang lainnya. Dalam data 1.6, citraan penglihatan dapat diketahui dari frasa die Rosen wieder glühen. Terdapat dua kata yang perlu digarisbawahi di sini, yaitu die Rosen yang berarti mawar dan glühen yang berarti bersinar. Yang dimaksud di sini mawar kembali bersinar adalah bagaimana indahnya bunga mawar yang mekar sehingga seolah-olah tampak di mata sedang bersinar. Sehingga tampak bahwa dalam baris ini, penyair berusaha menghadirkan gambaran nyata terkait bunga mawar yang indah tersebut untuk merangsang indera penglihatan pembaca. Tanpa indera penglihatan, maka indahnya bunga mawar yang mekar dan seolah-olah bersinar 
ini tidak akan bisa dengan jelas tergambar di benak pembaca. Dengan demikian, citraan yang ditampilkan adalah citraan penglihatan, sesuai dengan pernyataan Pradopo (2017) bahwa citraan penglihatan mendorong pembaca untuk membayangkan dan mendapatkan gambaran yang jelas terkait dengan fenomena atau objek yang digambarkan dalam puisi melalui indera penglihatan.

Selanjutnya, analisis pada data 1.7 dijabarkan sebagai berikut.

\subsection{Die Nebel zerreißen,}

Terjemahan : Kabut menghilang,

Data pada 1.7 dapat diartikan bahwa kabut tebal menghilang, sehingga seakan-akan pembaca bisa melihat kembali kondisi sekelilingnya. Berdasarkan hasil pembacaan secara heuristik pada seluruh isi puisi, hasil yang sama juga ditemukan. Penyair pada bait dan baris sebelumnya berusaha menggambarkan bagaimana tebalnya kabut yang ada sehingga indera penglihatan manusia tidak mampu melihat apapun, sedangkan melalui penggalan puisi pada 1.7 penyair membawa pembaca seakan-akan melihat bagaimana kabut menghilang. Dengan demikian, data 1.7 termasuk ke dalam citraan penglihatan. Hal ini sesuai dengan pernyataan Pradopo (2017) yang menyatakan bahwa citraan penglihatan merupakan rangsangan atau dorongan kepada indera penglihatan agar peristiwa yang tidak benar-benar terjadi seolah-olah terjadi dan terlihat oleh indera penglihatan manusia. Pernyataan ini juga didukung oleh pernyataan bahwa citraan penglihatan merupakan imaji yang melibatkan indera penglihatan manusia agar mendapatkan gambaran konkret atas suatu objek atau kejadian yang digambarkan dalam puisi [13].

Selanjutnya, analisis pada data 1.8 dijabarkan sebagai berikut.

\subsection{Der Himmel ist helle,}

Terjemahan : Langit cerah,

Hasil pembacaan heuristik yang peneliti lakukan pada penggalan puisi 1.8 menghasilkan makna bahwa langit cerah tidak tertutup awan atau hal-hal lain, di mana artinya matahari bersinar terang dan berwarna biru cerah. Gambaran fenomena ini mendorong pembaca untuk membayangkan mereka melihat hal ini secara nyata, di mana langit yang berwarna biru cerah, tidak tertutup awan, tidak ada kabut, sehingga dalam hal ini indera yang terlibat adalah indera penglihatan pembaca. Dengan melibatkan indera penglihatan, maka citraan yang dibentuk termasuk ke dalam citraan penglihatan. Pradopo (2017) menyatakan bahwa citraan penglihatan membuat pembaca membayangkan seolah-olah mereka melihat hal yang digambarkan dalam puisi secara nyata, sehingga pernyataan ini sesuai dengan data 1.8 [11]. Lebih lanjut, citraan penglihatan juga mendorong pembaca membayangkan objek atau fenomena dalam puisi melalui indera penglihatannya sehingga seakanakan nyata terlihat oleh pembaca [14].

\section{Citraan Pendengaran}

Citraan pendengaran merupakan imaji yang digunakan untuk mengajak pembaca seolah-olah mendengarkan apa yang dimaksud penyair melalui puisinya. Citraan pendengaran juga bisa berwujud suara-suara atau bunyi-bunyian yang disebutkan dalam puisi [15]. Pada dasarnya, citraan ini merangsang indera pendengaran pembaca agar seolah-olah mendengar suara atau bunyi yang dimaksud dalam puisi [16].

Dalam tabel 1, ditemukan 2 citraan pendengaran yang terdapat dalam puisi bertema musim gugur karya Goethe. Berikut dijabarkan hasil analisis kedua citraan pendengaran tersebut.

\subsection{Uns höret und zur rechten Zeit}

Terjemahan : Dengarkan kami di waktu yang tepat

Kata höret yang berarti dengarkan merupakan kunci dari citraan pendengaran pada penggalan puisi 2.1. Berdasarkan hasil pembacaan heuristik, makna penggalan puisi pada 2.1 merujuk pada suasana di musim gugur, di mana penyair ingin bunga-bunga mawar mendengarkan isi hati penyair. Melalui fenomena ini, ketika pembaca membaca penggalan puisi ini, pembaca seakan-akan dibawa untuk mendengarkan si penyair berbicara kepada bunga mawar. Dengan demikian, indera pendengaran pembaca pun seakan-akan dirangsang untuk mendengarkan suara yang dimaksud. Menurut Pradopo (2017), citraan pendengaran merupakan citraan yang mendorong indera pendengaran pembaca mendengar suara yang sebenarnya tidak pernah terjadi, sehingga berdasarkan pernyataan ini, penggalan puisi 2.1 merupakan citraan pendengaran [10]. Hal ini diperkuat oleh pendapat lain yang menyatakan bahwa citraan pendengaran berfungsi untuk mengajak atau membuat pembaca mendapatkan gambaran yang jelas dalam pikirannya terkait dengan suara atau bunyi yang dimaksud, meski sebenarnya suara tersebut tidak benar-benar terjadi [17]. 
Tidak jauh berbeda dengan 2.1, penggalan puisi pada 2.2 pun juga termasuk ke dalam citraan pendengaran, tetapi memiliki bentuk yang berbeda.

\subsection{Es säuseln die Winde}

Terjemahan: Angin berbisik

Kata säuseln yang berarti berbisik merupakan bentuk citraan pendengaran. Berdasarkan pembacaan heuristik, penggalan puisi 2.2 memiliki makna bahwa angin sedang bertiup pada musim gugur, menghasilkan gesekan-gesekan pada dedaunan yang gugur sehingga seakan-akan tengah berbisik. Di sini pembaca seolah-olah mendengar bagaimana bisikan-bisikan angin yang dimaksud dalam puisi. Dengan demikian, indera pendengaran pembaca seperti dilibatkan untuk membayangkan bagaimana suara bisikan sang angin. Maka, dapat disimpulkan bahwa penggalan puisi 2.2 termasuk ke dalam citraan pendengaran, sesuai dengan pendapat Pradopo (2017) yang menyatakan bahwa citraan pendengaran berusaha mengajak pembaca seakan-akan ikut mendengarkan suara yang dimaksud dalam puisi [10]. Senada dengan Pradopo, terdapat pendapat lain juga yang menyatakan bahwa citraan pendengaran tidak hanya berupa suara yang disebutkan dalam puisi, tetapi juga kata-kata lain yang bisa mendorong pembaca seolah-olah mendengarkan bunyian yang dimaksud maka dapat dikatakan sebagai citraan pendengaran [18].

\section{Citraan Perabaan}

Dalam Tabel 1, terdapat 2 citraan perabaan yang ditemukan. Citraan perabaan ini erat kaitannya dengan indera peraba manusia, yaitu kulit. Berikut dijelaskan hasil analisis data yang dilakukan.

\subsection{Euch kühlet des Mondes}

Terjemahan : Bulan mendinginkanmu

Berdasarkan pembacaan heuristik yang dilakukan peneliti secara keseluruhan terhadap isi puisi, penggalan puisi 3.1 memiliki makna bagaimana dinginnya kondisi saat musim gugur dimulai dengan latar situasi bulan yang seakan-akan menjadi penyebab dinginnya suhu pada saat itu. Suhu dingin inilah yang menjadi ciri dari citraan perabaan, karena permukaan yang dingin tersebut dirasakan oleh indera perabaan manusia. Citraan perabaan adalah citraan yang berusaha untuk membangun gambaran dalam benak pembaca tentang pengalaman sensoris yang melibatkan indera peraba manusia sehingga mampu merasakan permukaan suatu benda, baik itu panas, dingin, kasar, halus, dan lain-lain [10], sehingga sesuai dengan penggalan puisi 3.1 yang menggunakan kata dingin sebagai bagian dari citraan perabaan.

\subsection{Kalt der Kuss von deinem Munde}

Terjemahan : Dinginnya ciuman bibirmu

Selanjutnya pada penggalan puisi 3.2 , terdapat pula citraan perabaan. Bila dicermati, penggalan puisi 3.2 memiliki makna bahwa ada 2 pihak yang saling mencium, menempelkan bibir pada bibir, di mana hal ini memicu timbulnya rasa dingin yang menjalar pada bibir sebagai bagian dari kulit manusia. Rasa dingin yang timbul inilah yang menjadi bagian dari citraan perabaan. Pembaca di sini diajak untuk membayangkan dalam benak mereka secara jelas bagaimana rasa yang digambarkan dalam puisi, yaitu rasa dingin akibat dari bertemunya permukaan dingin ke kulit. Tujuannya adalah pembaca bisa mendapatkan gambaran konkret mengenai rasa dingin yang dialami penyair dalam puisinya. Hal ini sesuai dengan pernyataan Pradopo (2017) yang menyatakan citraan perabaan adalah citraan yang berusaha untuk memberikan gambaran mengenai rasa yang melibatkan indera peraba manusia [10]. Lebih lanjut, pernyataan lain juga menguatkan bahwa citraan perabaan lebih cenderung menggambarkan bagaimana rasa ketika manusia menyentuh suatu benda, misalnya dingin, panas, kasar, dan sebagainya sebagai akibat dari pengalaman sensoris dari indera perabanya [19], di mana pernyataan ini sesuai dengan data 3.2.

\section{Citraan Gerak}

Citraan gerak merupakan citraan yang menggambarkan suatu gerakan pada umumnya, atau sesuatu yang sebenarnya tidak bergerak tetapi seolah-olah bergerak [20]. Lebih lanjut, Pradopo (2017) juga menegaskan bahwa citraan gerak membuat gambaran dalam puisi menjadi lebih dinamis karena pembaca bisa mendapatkan gambaran mengenai gerakan yang dimaksud [10].

Merujuk pada kumpulan puisi bertema musim gugur karya Goethe, ditemukan 3 citraan gerak. 3 citraan ini kemudian dijelaskan sebagai berikut.

\subsection{Willst du immer weiter schweifen?}

Terjemahan : Apakah kamu ingin terus mengembara?

Penggunaan kata schweifen yang berarti mengembara merupakan salah satu ciri dari citraan gerak. Kata mengembara di sini menunjukkan pergerakan, yaitu berpindah dari satu tempat ke tempat yang lain. Secara keseluruhan, makna pada 
penggalan puisi 6.1 merujuk pada pertanyaan mengenai tokoh $D u$ yang berarti kamu ini apakah akan terus melakukan perjalanan dari satu tempat ke tempat lain. Dengan demikian, pembaca dapat membayangkan ketika membaca penggalan ini, gambaran yang didapatkan adalah ada sesorang yang sedang melakukan perjalan dari satu tempat ke tempat lainnya. Sehingga penggalan puisi 6.1 merupakan bentuk citraan gerak, di mana hal ini sesuai dengan pernyataan Pradopo yang menyatakan bahwa citraan gerak merupakan bentuk penggambaran suatu gerakan agar bisa dibayangkan dalam benak pembaca secara nyata sehingga seolah-olah pembaca sedang bergerak atau melihat gerakan tersebut [10].

\subsection{Rühret sich der Wein im Fasse,}

Terjemahan : Anggur mengaduk di dalam tong, Lebih lanjut, citraan gerak juga ditemukan di dalam penggalan puisi 6.2. Hal ini dapat dicermati dari kata Rühret yang berarti mengaduk/mengocok. Subjek yang digunakan dalam penggalan puisi 6.2 adalah der Wein yang berarti minuman wein atau anggur. Subjek tersebut digambarkan sedang melakukan pekerjaan layaknya seorang manusia, yaitu mengaduk sesuatu di dalam tong. Melalui makna ini, maka dapat diketahui bahwa penggalan puisi 6.2 merupakan citraan gerak, di mana hal ini senada dengan pernyataan bahwa citraan gerak merupakan imaji yang menggambarkan pergerakan yang dilakukan sehingga pembaca dapat beranganangan mengenai gerakan tersebut [10].

\subsection{Die Welle wieget unsern Kahn}

Terjemahan: Ombak mengguncang perahu kami Selanjutnya, pada penggalan puisi 6.3 , penggunaan kata kerja wieget yang berarti mengguncang merupakan salah satu bentuk citraan gerak. Mengguncang di sini bermakna menggerakkan perahu sehingga tampak terombang-ambing di lautan. Pembaca dibawa oleh penyair melalui penggalan puisi ini untuk membayangkan bagaimana ombak bergerak dan mengguncangkan si perahu. Sehingga dapat disimpulkan bahwa pada penggalan puisi 6.3 terdapat citraan gerak, senada dengan pernyataan dari Pradopo (2017) bahwa citraan gerak adalah penggambaran suatu gerakan yang sebenarnya tidak terjadi tetapi seolah-olah terjadi [10]. Pernyataan Pradopo juga diperkuat dengan pernyataan bahwa citraan gerak lebih banyak menggunakan kata kerja-kata kerja yang cenderung menghasilkan suatu gerakan dari subjek dalam puisi, sehingga pembaca mendapatkan angan-angan yang konkret mengenai gerakan yang dimaksud [21].

\section{KESIMPULAN}

Dari pembahasan di atas, maka dapat disimpulkan bahwa makna dalam citraan dapat diketahui dengan cara memahami keseluruhan teks dalam puisi secara komprehensif. Pada penelitian ini, makna citraan penglihatan akan merujuk pada bendabenda konkret, bukan sekadar konsep abstrak yang terkadang juga dapat melibatkan indera penglihatan. Kemudian citraan gerak berkaitan dengan suatu upaya perpindahan, sedangkan citraan pendengaran berkaitan dengan bunyi atau suara yang dapat didengar oleh indera pendengaran. Kemudian citraan perabaan merujuk pada konsep bagaimana indera peraba manusia merasakan hal yang dimaksud, yaitu dingin, panas, atau terbakar, dan lain-lain. Lebih lanjut, Pradopo membagi citraan dalam teorinya menjadi 7 jenis, namun dalam penelitian ini hanya ditemukan 4 jenis citraan dalam puisi bertema musim gugur karya Goethe, yaitu citraan penglihatan, citraan pendengaran, citraan perabaan, dan citraan gerak. Jumlah dari masing-masing citraan tersebut yaitu 8 citraan penglihatan, 2 citraan pendengaran, 2 citraan perabaan, dan 3 citraan gerak.

\section{REFERENSI}

[1] A. R. Febiyanti, "Citraan Pada Puisi Das Göttliche Karya Johann Wolgang Von Goethe," Universitas Negero Yogyakarta, 2014.

[2] J. Sitaniapessy, I., Arbie, R., \& Sahetapy, "Refleksi Masyarakat Terhadap Ketuhanan Dalam Antologi Puisi Johan Wolfgang von Goethe," J. Elektron. Fak. Sastra Univ. Sam Ratulangi, vol. 17, 2021.

[3] M. P. Laila, "Citraan dalam Kumpulan Puisi Mangkutak di Negeri Prosaliris Karya Rusli Marzuki Saria," J. Gramatika, vol. 2, no. 1, 2016.

[4] A. S. Al-Zubaidy, "The Language of Poetry: Tool or Performance? A Stylistic Analysis of a Classical Arabic Line of Verse.," Procedia - Soc. Behav. Sci., vol. 5, no. 11, 2014.

[5] Y. K. Kom, "Gaya Bahasa dan Citraan Pada Kumpulan Puisi Bilang Begini Maksudnya Begitu Karya Sapardi Djoko Damono," 2019. . 
[6] W. Metzig, Bildhafte Vorstellungen als Gedächtnisklammern. Berlin, Heidelberg: Springer, 2020.

[7] E. Creely, “'Poetry Is Dying': Creating A (Re) New (Ed) Pedagogical Vision For Teaching Poetry," Aust. J. Lang. Lit., vol. 42, no. 2, 2019.

[8] H. Shalihah, "Interpretasi Puisi Wanderers Nachtlied Karya Johann Wolfgang Von Goethe Dengan Metode Vierfarb," Universitas Negeri Jakarta, 2020.

[9] Y. Anastasia, "Motif Kematian Di Era Romantik Dalam Lima Puisi Karya Heinrich Heine," Universitas Padjajaran, 2015.

[10] N. R. Marsela, "Analisis Citraan Dalam Antologi Puisi Rumah Cinta Karya Penyair Jambi," Aksara J. Ilm. Pendidik. Bhs. dan Sastra Indones., vol. 2, no. 2, 2018.

[11] R. D. Pradopo, Pengkajian Puisi. Yogyakarta: Gadjah Mada University Press, 2017.

[12] A. Komariah, Metodologi Penelitian Kualitatif. Jakarta: litbang.kemenkes.go.id., 2018.

[13] W. C, "Phänomenologie der visuellen Einbildungskraft: in Goethes Gedicht Die Metamorphose der Pflanzen," 2014.

[14] B. Schäffer, "Die Versprachlichung des Bildes in bildhafter Sprache oder: Ikonizität und Metaphorik-zwei Seiten einer Medaille Dokumentarische Methode. Grundlagen.
Entwicklungen. Anwendungen.," Opladen J., pp. 224-242, 2013.

[15] L. Yafeng, "Research on Cultural Imagery in Poetry Translation," J. Jixi Univ., vol. 2, 2016.

[16] F. Sadeghitabar, "A Study of Imagery in the Poetry of Blind Poets with an Emphasis on Shurideh Shirazi and Mahin Zoraqi," $J$. Poet. Stud. (boostan Adab., vol. 10, no. 3, 2018.

[17] X. G. Hao, "The Construction and Analysis of Annotated Imagery Corpus of Three Hundred Tang Poems.," 2019.

[18] P. Y. Perdana, "Figurative Language And Imagery In William Shakespeare's Selected Sonnets," Hasanuddin University, 2017.

[19] A. Sulaeman, "Analisis Citraan Pada Kumpulan Puisi 'Doa Untuk Anak Cucu' Karya Ws Rendra," J. Perspekt. Pendidik., vol. 1, no. 10, 2016.

[20] A. A. Anderson, "Imagery And How It Works In Lorca's Poeta En Nueva York: The Case Of '1910 (Intermedio)," 2021.

[21] W. A. Matar, "Formation Of Imagery In AlHamshari Poems In The Electronic Encyclopedia Of Modern Poetry," The. Palarch's J. Archaeol. Egypt/Egyptology, vol. 17, no. 6, 2020. 